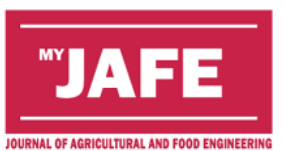

\title{
Optimizing hydrogen production from the Landfill Leachate by electro-coagulation technique
}

Hasfalina Che Man a*, Chai Yun Xie a, Khairul Faezah Md Yunos b, Abdulsalam Mohammed c, Muhammad Hazwan Hamzah a

aDepartment of Biological and Agricultural Engineering, Faculty of Engineering, Universiti Putra Malaysia, 43400, UPM Serdang, Selangor, Malaysia

${ }^{b}$ Department of Food and Process Engineering, Faculty of Engineering, Universiti Putra Malaysia, 43400, UPM Serdang, Selangor, Malaysia.

cDepartment of Agricultural and Bio-resources, Ahmadu Bello University, 810107, Zaria, Nigeria.

\section{ARTICLE HISTORY}

Received: 31 March 2020

Received in revised form: 5

September 2020

Accepted: 7 September 2020

Available Online: 7 October 2020

\section{Keywords}

Optimization

Electro-Coagulation;

Hydrogen gas;

Landfill leachate;

Response surface methodology (RSM)

\section{Abstract}

The loss and impact of non-renewable fossil energy on global warming concerns are prompting to intensive research to find viable, less emissions-oriented alternative energies. The present work aims to study the potential of hydrogen gas production (for renewable energy) by electrocoagulation process from landfill leachate. The Design-Expert software for response surface methodology (RSM) was used to investigate the process variables in the hydrogen production system. The effects of three independent variables; namely $\mathrm{pH}$ (4-8) and voltage (3-9 V), using different types of electrodes ( $\mathrm{Al}, \mathrm{Fe}$, and $\mathrm{Ni}$ ) were studied. At the optimal condition of voltage $9 \mathrm{~V}$ and initial $\mathrm{pH} 6$ at 20 minutes, the $\mathrm{Al}$ electrode recorded an upturn maximum $\mathrm{H}_{2}$ yield of 697 ppm, while 554 and 551 ppm were obtained with $\mathrm{Ni}$ and $\mathrm{Fe}$ electrode, respectively. Moreover, the coefficient of determination $\left(\mathrm{R}^{2}\right)$ showed a good relationship between actual and expected results.

\section{Introduction}

Hydrogen gas is widely considered as a fuel of the future due to its properties of rapid burning speed, no emissions of greenhouse gases, higher energy density, low minimum ignition energy and a very high research octane number (Nanthagopal et $a l, 2011$ ). Currently, $95 \%$ of global hydrogen production is from fossil fuel sources, primarily via the steam reforming of natural gas (Ogden, 1999). Many other methods like the thermocatalytic reformation of hydrocarbons, electrolysis and thermolysis of water are also known as industrial hydrogen production methods (Demirbas et al., 2011). Though, the simultaneous generation of unwanted oxygen with hydrogen limits the scope of large scale hydrogen production through these methods, particularly the electrolysis of water (Smolinka et al., 2009).

However, Electrocoagulation (EC) technology is a treatment process which involves introducing electrical current to treat the contaminants by adding coagulant. Shammas et al. (2010) stated that coagulation is capable of removing small particles inside the contaminants setting them into motion with the applied current into it besides reducing residue for waste production. EC has the capability to remove a large range of pollutants under a variety of conditions, including suspended solids, metals, petroleum products, colour from dye solutions, and aquatic humus, and can be used for the de-fluoridation of water (HOLT, 1999). This shows that the treatment conditions (such as pH, voltage, electrode types etc.) have considerable influences on the performance of the EC process. For instance, Shivayogimath et al., (2014) investigate the effect of $\mathrm{pH}$ values (4, 5.8 and 8) on the removal of COD during 40 minutes of a batch run at an applied cell voltage of $3 \mathrm{~V}$. It was observed that for all three $\mathrm{pH}$ values, the COD removals increased with an increase in reaction time. However, the optimum COD removal was observed at $\mathrm{pH}$ value of 5.8. At this $\mathrm{pH}$, COD was reduced from $4820 \mathrm{mg} / \mathrm{L}$ to $2250 \mathrm{mg} / \mathrm{L}$ with 35 minutes of the reaction period giving COD removal efficiency of $53.3 \%$. Similarly,
Abdallah et al., (2013) validated that pH could significantly influence both hydrogen and oxygen production. The results of experimentation indicate that within the range of $\mathrm{pH}$ from 3 to 13 , the further $\mathrm{pH}$ levels get from $\mathrm{pH} 7$ gives better hydrogen and oxygen production. More so, according to Song et al. (2008), it determined that $96 \%$ of coloured and $80 \%$ TOC was removed by an ozone electro-coagulator with an optimum $\mathrm{pH}$ of 10 , dye concentration of $100 \mathrm{mg} / \mathrm{L}$, a current density of $10 \mathrm{~mA} / \mathrm{cm}^{2}$, salt concentration of $3,000 \mathrm{mg} / \mathrm{L}$, the temperature of 30 degrees Celsius, ozone flow rate of $20 \mathrm{mg} / \mathrm{L}$, and electrode distance of 3 $\mathrm{cm}$. The second study as in Sengil et al. (2009) were able to decolourize $98 \%$ of Reactive Black 5 from synthetic wastewater by using electrocoagulation with iron electrodes. Optimum conditions for treatment include dye concentration of $100 \mathrm{mg} / \mathrm{L}$, $\mathrm{pH}$ of 5, a current density of $4.575 \mathrm{~mA} / \mathrm{cm}^{2}$, the salt concentration of $3,000 \mathrm{mg} / \mathrm{L}$, the temperature of 20 degrees Celsius, and inter-electrode distance of $2.5 \mathrm{~cm}$. Furthermore, it has been reported that the removal efficiency of electrocoagulation using $\mathrm{Al}$ electrodes is higher than that of $\mathrm{Fe}$ electrodes (Wang., 2009). Ilhan, (2008) reported that $\mathrm{Al}$ electrodes give better $\mathrm{COD}$ and $\mathrm{NH}_{3} \mathrm{~N}$ removal of $56 \%$ as against $35 \%$ for the Fe electrode under the same treatment conditions. For economic operating conditions when using Al electrodes, Shivayogimath et al. (2013) concluded the $\mathrm{pH}$ of 6 with a voltage of $9 \mathrm{~V}$ ensures optimal hydrogen yield.

Noticeably, leachate possesses the ability to produce hydrogen gas via electrocoagulation at yields near the theoretical maximum of $4 \mathrm{~mol} \mathrm{H}_{2} / \mathrm{mol}$ of hexose consumed (Pawar et al., 2013). However, the EC process on leachate for hydrogen production is still not widely being introduced to the industries. Little studies have been done on hydrogen gas production using leachate and it is crucial to solving the leachate problem due to the massive amount of accumulation of wastes nowadays in which affect the environment thoroughly in decades. In this regards, this study focusses mainly on investigating the potential of hydrogen gas production by EC 
process using different types of electrodes ( $\mathrm{Al}, \mathrm{Ni}$ and $\mathrm{Fe}$ ) and then optimize the operation conditions ( $\mathrm{pH}$ and voltage) by response surface methodology (RSM).

\section{Materials and methods}

\section{Materials source}

About 75 litres of leachate samples were collected from one of the treatment plants at Selangor in Malaysia for electrocoagulation process. Initially, the samples were stored in a chiller at a temperature of 4 degrees Celsius. Three different types of electrodes (Aluminium, Nickel, Iron) of identical dimensions (Length $\mathrm{x}$ width $\mathrm{x}$ depth: $150 \mathrm{~mm} \times 50 \mathrm{~mm} \times 1.20$ $\mathrm{mm}$ ), DC-voltage rectifier with a varying device (BK PRECISION - DC regulated power supply model 1621A), gas bag along with delivery tube (TEDLAR 0.6 LITRES) and acidic buffer solutions (prepared sulphuric solution) were sourced and used in the subsequent experiments.

\section{Physicochemical characteristics of leachate}

The collected leachate was sent for analysed by laboratory using several methods reference such as APHA 25508 and inhouse method (QWI-CH/17-33) to determine its characteristics for comparison with the result obtained from the experiment conducted. Characteristics such as temperature, $\mathrm{pH}$, Biochemical Oxygen Demand (BOD), Chemical Oxygen Demand (COD), total suspended solids (TSS), copper, aluminium, zinc and others properties were analysed in accordance with the ALS Technichem. The composition of the biogas produced from each experiment by the leachate was determined by using a gas detector (Crowcon).

\section{Experimental set-up}

The electro-coagulation experimental setup for this study is presented in Figure 1. It should be noted that the experimental set was applied distinctly for the three types of electrodes (Al, Ni and $\mathrm{Fe}$ ) considered in this study. This shows that electrodes were continuously changed. Initially, $800 \mathrm{ml}$ of the leachate sample was filled into the glass container of $1.3 \mathrm{~L}$. The glass container was placed on the hot plate magnetic stirrer (E) while the instalment of electrodes plates (A and B) was connected to the power supply for adjusting different voltage (F) throughout the experiment. After each experiment has done, the gas collected in the gas bag (D) through the delivery tube (C) will be transferred out using a syringe into the Crowcon gas analyser. The volume of gas in ppm will be detected and shown in the device for comparing and recording.

\section{Experimental layout and performance optimisation}

Design-Expert version 7.0 was used to develop the experimental layout based on the considered two independent factors (voltage and $\mathrm{pH}$ ). The developed experimental layout was applied undependably using the selected electrodes (Al, Ni and $\mathrm{Fe}$ ). The summary of the experimental layout is presented in Table 1. The experimental factors were varied to different levels which range from 4-8 and 3-9V for the $\mathrm{pH}$ and voltage, respectively.

The central composite design (CCD) component of the response surface methodology (Design-Expert version 10.0) was employed in the optimization of hydrogen gas production from the electrocoagulation process through leachate as a substrate. Based on the experimental layout, a total of 13 runs of experiments were required to perform with 4 replications of the centre point. The regression model was calculated by analysing the analysis of variance (ANOVA), p-and F-value. The adequacy of the model was expressed by the coefficient of determination, $\mathrm{R}^{2}$ followed by the predicted- $\mathrm{R}^{2}$ and adjusted $\mathrm{R}^{2}$ value. The model describes the interaction among the parameters influencing the response by varying them concurrently by $3 \mathrm{D}$ surface graph and ANOVA. The value of $\mathrm{R}^{2}$ was compared to visualize the modelling abilities towards the experimental data. Hence, readings of predicted values against the experimental values were plotted and investigated for its suitability for optimal conditions. These procedures were applied distinctly for the three types of the electrodes considered in this study, and then the $\mathrm{H}_{2}$ yield under the varying conditions was compared.

Table 1. Summary of the CCD experimental layout for the combined $\mathrm{pH}-\mathrm{X} 1$ and voltage-X2 factors

\begin{tabular}{lllll}
\hline Variable & Parameters & Level & \\
\cline { 3 - 5 } & & +1 & 0 & -1 \\
\hline $\mathrm{X}_{1}$ & $\mathrm{pH}-\mathrm{A}$ & 4 & 6 & 8 \\
$\mathrm{X}_{2}$ & Voltage (V)- B & 3 & 6 & 9 \\
\hline
\end{tabular}

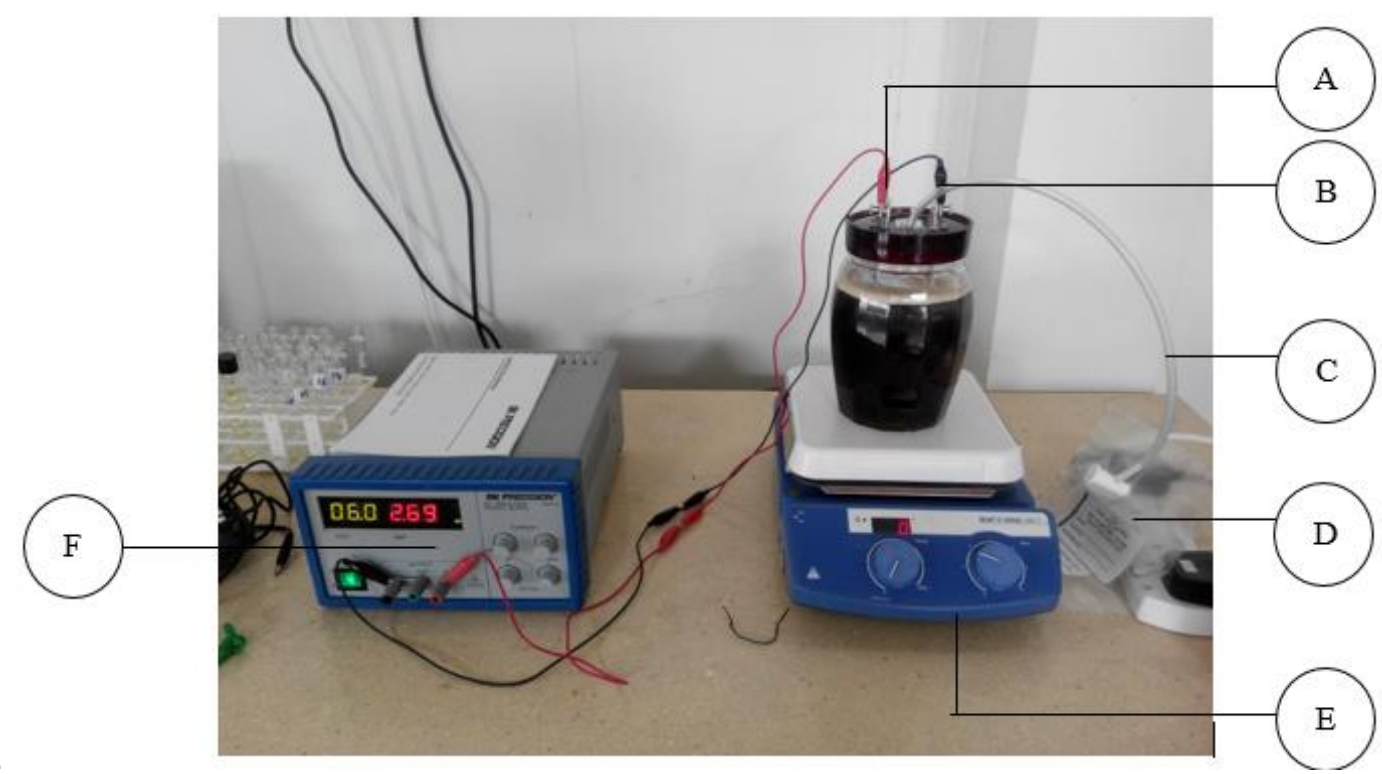

Figure 1. Experiment set-up for the electrocoagulation process for $\mathrm{H}_{2}$ production from leachate (A-anode wiring, B-cathode wiring, Ctubing of gas flow, D-gas bag 0.6L, E-hot plate magnetic stirrer, F-DC regulated power supply) 


\section{Analytical methods}

At the end of each experiment using a particular type of the electrodes, the collected hydrogen gas in the gas-bag was retrieved with a syringe, $\mathrm{H}$ (TERUMO $60 \mathrm{ml})$ and then analysed using Crowcon gas analyser, $\mathrm{G}$ (as depicted in Figure 2). Also, the physicochemical characteristics of the leachate were analysed using calorimetric methods in accordance with APHA, 2005.

\section{Results and discussion}

\section{Physicochemical characteristics}

Table 2 presents the physicochemical properties of the leachate sample alongside the Malaysian discharge limit. Virtually all the examined parameters exceed the standard limits, and this further confirms that releasing of such waste without proper remediation is unhealthy for the environment. It was only the $\mathrm{pH}$ that can be considered within the acceptable limit, but as for the other parameters they were far above the Department of Environment Malaysia (DOE) limit (Table 2). Though, reports have shown that the level of contaminants concentrations in leachates depends on several factors such as deposition durations, method of depositions, environmental factors as well as the types of waste (Kabuk et al., 2013; Shivayogimath et al., 2013).

\section{Experimental results}

Based on the CCD experimental layout, the treatments were applied and the corresponding hydrogen gas produced using $\mathrm{Al}$; $\mathrm{Ni}$ and Fe electrode were recorded into the experimental matrix, as presented in Table 3. Essentially, the three electrodes were subjected to similar treatment conditions.

In overview, the highest volume of 809 ppm of the hydrogen gas was obtained at $9 \mathrm{~V}$ voltage and $\mathrm{pH}$ of 4 with Ni electrode. While, 697 and $554 \mathrm{ppm}$ were recorded with $\mathrm{Al}$ and $\mathrm{Fe}$ electrodes, respectively. At this same voltage magnitude of $9 \mathrm{~V}$ but $\mathrm{pH}$ of 8 , the $\mathrm{H} 2$ yield with $\mathrm{Ni}$ reduced to 538, while for $\mathrm{AL}$ and Fe electrode remains approximately stable at 696 and 551, respectively. On the contrary, as the voltage reduced to $2-3 \mathrm{~V}$, the $\mathrm{H}_{2}$ yield using $\mathrm{Ni}$ electrode dramatically reduced to $77 \mathrm{ppm}$ and this recorded the least hydrogen gas production in this study. At treatment condition of $6 \mathrm{~V}$ and $\mathrm{pH}$ of 6 , an upturn performance

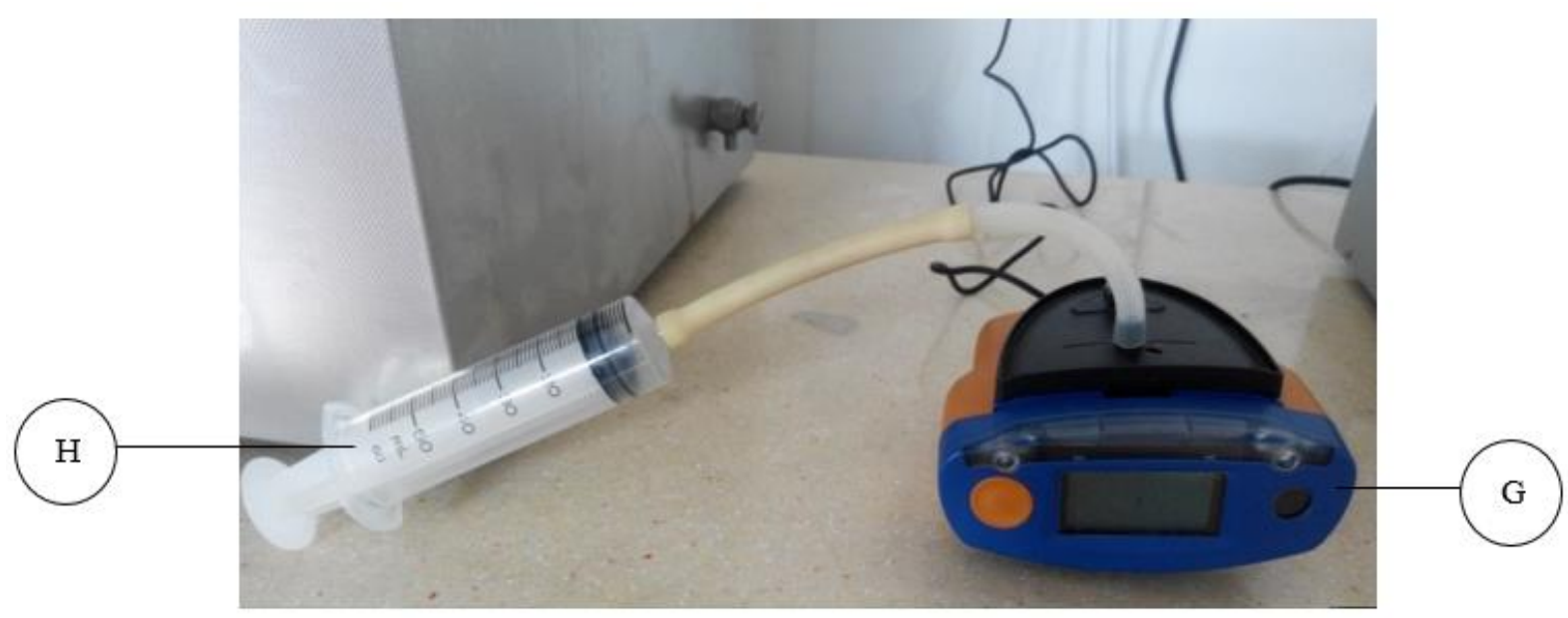

Figure 2. Setup for gas analysis using the Crowcon Analyser

Table 2. Physiochemical characteristics of the leachate sample

\begin{tabular}{llll}
\hline Parameters & Unit & Leachate & DOE Standards \\
\hline $\mathrm{pH}$ & -- & 9.7 & $6-9$ \\
Temperature & ${ }^{\circ} \mathrm{C}$ & 20.8 & 20 \\
Total Suspended Solid (TSS) & $\mathrm{mg} / \mathrm{L}$ & 870 & 50 \\
Biochemical Oxygen Demand (BOD) & $\mathrm{mg} / \mathrm{L}$ & 1610 & 20 \\
Chemical Oxygen Demand (COD) & $\mathrm{mg} / \mathrm{L}$ & 4340 & 120 \\
Ammonia-N & $\mathrm{mg} / \mathrm{L}$ & 2440 & 50 \\
Free Chlorine & $\mathrm{mg} / \mathrm{L}$ & $<0.5$ & \\
\hline
\end{tabular}

Table 3. Experimental matrix for treatment factors with respective $\mathrm{H}_{2}$ values for the electrodes

\begin{tabular}{|c|c|c|c|c|c|}
\hline \multirow[b]{2}{*}{ Run } & \multirow{2}{*}{$\begin{array}{l}\text { Factor } 1 \\
\mathrm{~A}: \mathrm{pH}\end{array}$} & \multirow{2}{*}{$\begin{array}{l}\text { Factor } 2 \\
\text { B: Voltage }\end{array}$} & \multicolumn{3}{|c|}{ Hydrogen Gas (ppm) } \\
\hline & & & Al-Electrode & Ni-Electrode & Fe-Electrode \\
\hline 1 & 9 & 6 & 510 & 332 & 422 \\
\hline 2 & 8 & 9 & 696 & 538 & 551 \\
\hline 3 & 4 & 6 & 463 & 450 & 262 \\
\hline 4 & 6 & 6 & 697 & 683 & 550 \\
\hline 5 & 4 & 3 & 153 & 77 & 101 \\
\hline 6 & 6 & 6 & 697 & 690 & 546 \\
\hline 7 & 4 & 9 & 697 & 809 & 554 \\
\hline 8 & 6 & 6 & 697 & 554 & 551 \\
\hline 9 & 6 & 2 & 151 & 89 & 109 \\
\hline 10 & 8 & 3 & 156 & 108 & 103 \\
\hline 11 & 6 & 2 & 173 & 77 & 109 \\
\hline 12 & 6 & 6 & 695 & 550 & 551 \\
\hline 13 & 6 & 6 & 600 & 457 & 552 \\
\hline
\end{tabular}


of $697 \mathrm{ppm}$ was obtained with the Al electrode as against 554 and 551 ppm for the $\mathrm{Ni}$ and Fe electrodes, respectively. It can be noticed that higher voltage favours more hydrogen gas production. This remark is in strong agreement with previous studies (Shivayogimath et al., 2013; Bazrafshan E. et al., 2007 and Yao Hua Ch. et al., 2008).

\section{Analysis of variance (ANOVA) and regression model}

The results of the analysis of variance for the $\mathrm{H}_{2}$ yield data obtained for the three electrodes are as shown in Table 4. The Model F-value of $64.90,21.42$ and 24.34 for the $\mathrm{Al}, \mathrm{Ni}$ and $\mathrm{Fe}$ imply the model is significant at $\mathrm{P}<0.05$ and there is only 0.01 $0.04 \%$ chance of disturbance due to noise (Table 4 ). In this analysis, a "Prob > F" value less than 0.0500 indicate model terms are significant. Thus, it is obvious that the regression analysis of the experimental design for the Al-electrode shows that the linear model terms $\mathrm{B}$ (Voltage) and the two quadratic model term $\left(\mathrm{A}^{2}\right.$ and $\left.\mathrm{B}^{2}\right)$ are significant at this confidence level $(\mathrm{P}<0.05)$ with respective $\mathrm{F}$-values of $146.37,39.00$ and 26.48 . It can be noticed that the only significant terms when the $\mathrm{Ni}$ electrode was used were $B$ and the quadratic term of $A^{2}$, and the corresponding F-values were 56.24 and 8.75 , respectively. The Fe electrodes show a similar response to that of Al. The significant terms were $\mathrm{B}, \mathrm{A}^{2}$ and $\mathrm{B}^{2}$, with corresponding F-values of $57.99,16.68$ and 7.68 , respectively. In recap, it can be noticed that in all the three regression analysis B-linear term (voltage) is highly significant but its quadratic term only shows some effect $\mathrm{Al}$ and $\mathrm{Fe}$ electrode. However, the linear term $\mathrm{A}(\mathrm{pH})$ was not significant irrespective of the type electrodes. Thus, the regression model for the $\mathrm{H}_{2}$ production based on the significant terms using $\mathrm{Al}, \mathrm{Ni}$ and $\mathrm{Fe}$ electrodes were as expressed in Eq. 1, 2 and 3 , respectively.

$$
\begin{aligned}
& H_{2-\text { Al Electrode }}=691.32+257.69 \times B-131.57 \times A^{2} \\
& -115.92 \times B^{2} \\
& H_{2-N i \text { Electrode }}=581.11+281.65 \times B-109.89 \times A^{2} \\
& \begin{aligned}
H_{2-\text { Fe Electrode }}= & 538.06+218.35 \times B-115.82 \times A^{2} \\
& -84.04 \times B^{2}
\end{aligned}
\end{aligned}
$$

The fit of the regression models for the three electrodes was also expressed by the coefficients of determinations $\mathrm{R}^{2}$, which were found to be $0.9789,0.9387$ and 0.9251 for the $\mathrm{Al}, \mathrm{Ni}$ and $\mathrm{Fe}$ electrodes, respectively. The data were further diagnosed by plotting a linear graph between the actual and predicted values, as presented in Figure $3 \mathrm{a}, \mathrm{b}$ and c, respectively. It can be observed that the data points were all around the diagonal line, and this implies insignificant deviations. More so, the respective adjustable and predicted $\mathrm{R}^{2}$ values were $(0.9638 ; 0.5123)$, $(0.8948 ; 0.6374)$ and $(0.8165,0.6021)$. Thus, the excellent correlation values $\mathrm{R}^{2}$ shows that the regression models are adequate to navigate the design space, and as such, they are suitable for predicting the $\mathrm{H}_{2}$ yield.

\section{Response surface of the synergistic effect of treatment factors on the optimal hydrogen gas production}

As shown in Figure 4a, b and c, hydrogen gas production increases with the voltage but decreases gradually as the voltage decreases to lower ranges. The surface response alongside with contour of Figure 4a, based on the optimization criterion, the optimal hydrogen yield (697 ppm) was obtained at the voltage $9 \mathrm{~V}$ and $\mathrm{pH}$ of 6 with $\mathrm{Al}$ electrode, though the corresponding predicted value was $833.091 \mathrm{ppm}$. More so, Figure 4(b) illustrated the optimized condition for $\mathrm{H}_{2}$ production using the $\mathrm{Ni}$ electrode. Similarly, higher voltage $(9 \mathrm{~V})$ favours $\mathrm{H} 2$ production with an optimal yield of $554 \mathrm{ppm}$ and the predicted values of $617.391 \mathrm{ppm}$, but this is considerably lower compared to that of the Al-electrode. This observation is in good agreement with the report of Shivayogimath et al., (2013). Furthermore, Figure 4(c) depicts the surface response of the combined effect of voltage and $\mathrm{pH}$ on the optimal hydrogen production using the Fe. An optimal value of $551 \mathrm{ppm}$ with a corresponding predicted value of $672.372 \mathrm{ppm}$ was obtained. Generally, it can be noticed from these figures that the impact of the $\mathrm{pH}$ on the $\mathrm{H}_{2}$ yield was not significant. Bazrafshan E. et al., 2007 and Yao Hua Ch. et al., 2008 anonymously reported that the increase in $\mathrm{pH}$ may be as a result of hydrogen evolution at the cathodes electrode. On the contrary, Chafi et al. 2011 contested that the surge in $\mathrm{pH}$ was only due to the release of $\mathrm{CO}_{2}$ from the wastewater, though $\mathrm{H}_{2}$ bubble were generated as disturbance during the process. They further explained that, at lower $\mathrm{pH}$, the $\mathrm{CO}_{2}$ is over-saturated in wastewater and as such $\mathrm{H}_{2}$ releases and then causing an increase in the $\mathrm{pH}$ value. In this study, the $\mathrm{pH}$ did not affect the treatment processes significantly despite the wide range of the variation, (4-8).

\section{Conclusion}

The electrocoagulation process based on varying voltage and $\mathrm{pH}$, using different types of electrodes ( $\mathrm{Al}, \mathrm{Ni}, \mathrm{Fe}$ ) for hydrogen production from leachate was successfully optimized using response surface methodology (RSM). CCD optimization component of RSM was applied in this study and the results show that the $\mathrm{Al}$ electrodes give an upturn optimum $\mathrm{H}_{2}$ yield of $697 \mathrm{ppm}$ at the most suitable treatment parameters of $\mathrm{pH} 6$ with the voltage of $9 \mathrm{~V}$ for 20 min treatment durations. While, the $\mathrm{H}_{2}$ yield under this same conditions using $\mathrm{Ni}$ and Fe electrodes were 554 and 551 ppm, respectively. The respective model coefficient of correlation $\left(\mathrm{R}^{2}\right)$ for the experimental and predicted $\mathrm{H}_{2}$ value were $0.9789,0.9387$ and 0.9251 . This shows the precision of the regression model is adequate to navigate the design space, and as such, it can be efficiently used for the

\begin{tabular}{|c|c|c|c|c|c|c|}
\hline \multirow[t]{2}{*}{ Source } & \multicolumn{2}{|c|}{ Al-Electrode } & \multicolumn{2}{|c|}{ Ni-Electrode } & \multicolumn{2}{|c|}{ Fe-Electrode } \\
\hline & F-Value & Prob $>F$ & F Value & Prob > F & F Value & Prob $>$ F \\
\hline Model & 64.90 & $<0.0001$ & 21.42 & 0.0004 & 24.34 & 0.0003 \\
\hline$A-p H$ & 3.84 & 0.0843 & 0.86 & 0.3837 & 3.34 & 0.0758 \\
\hline$B$-Voltage & 146.37 & $<0.0001$ & 56.24 & 0.0001 & 57.99 & 0.0001 \\
\hline$A B$ & $1.005 E-003$ & 0.9756 & 3.28 & 0.1132 & $2.465 E-004$ & 0.9879 \\
\hline$A^{2}$ & 39.00 & 0.0004 & 8.75 & 0.0211 & 16.68 & 0.0047 \\
\hline$B^{2}$ & 26.48 & 0.0013 & 3.70 & 0.0957 & 7.68 & 0.0276 \\
\hline$R^{2}$ & 0.9789 & & 0.9387 & & 0.9251 & \\
\hline$A d j-R^{2}$ & 0.9638 & & 0.8948 & & 0.8165 & \\
\hline Pred-R ${ }^{2}$ & 0.5123 & & 0.6374 & & 0.6021 & \\
\hline
\end{tabular}
prediction of hydrogen production from leachate under the electrocoagulation process conditions.

Table 4. Analysis of variance (ANOVA) of the model for $\mathrm{H} 2$ production using $\mathrm{Al}$, $\mathrm{Ni}$ and Fe electrode 
Design-Expertis Software Hydrogen Gas

Color points by value of Hydrogen Gas:

700

151

(a)

Al-Electrode

Design-Expert@ Softw are Hydrogen Gas

Color points by value of Hydrogen Gas:

$\prod^{809}$

(b)

$\mathbf{N i}$-Electrode

(c)

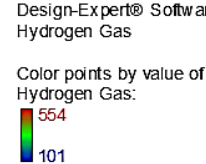

101

Fe-Electrode

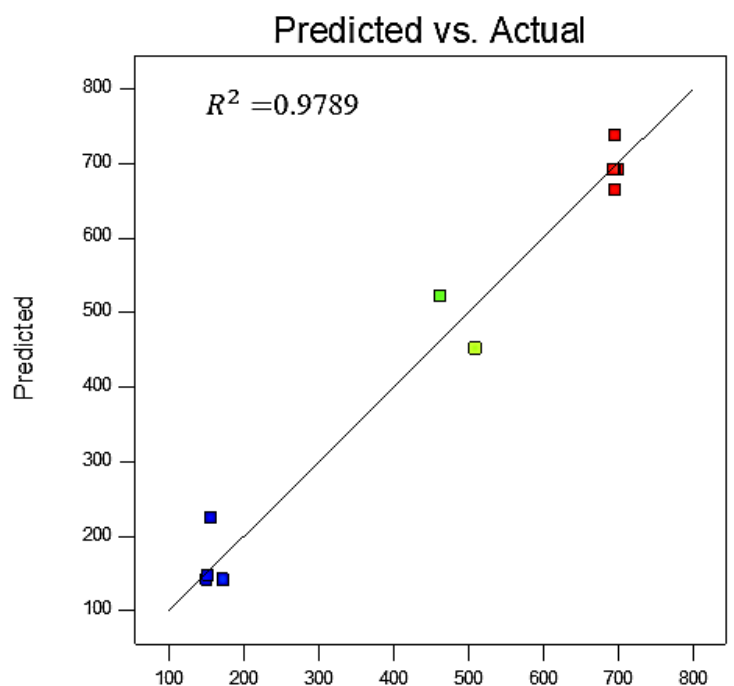

Actual

Predicted vs. Actual

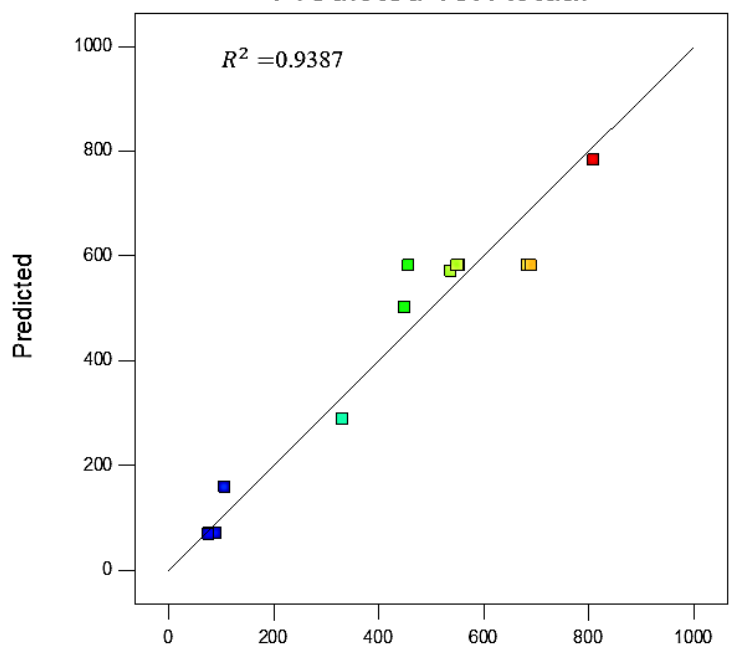

Actual

Predicted vs. Actual

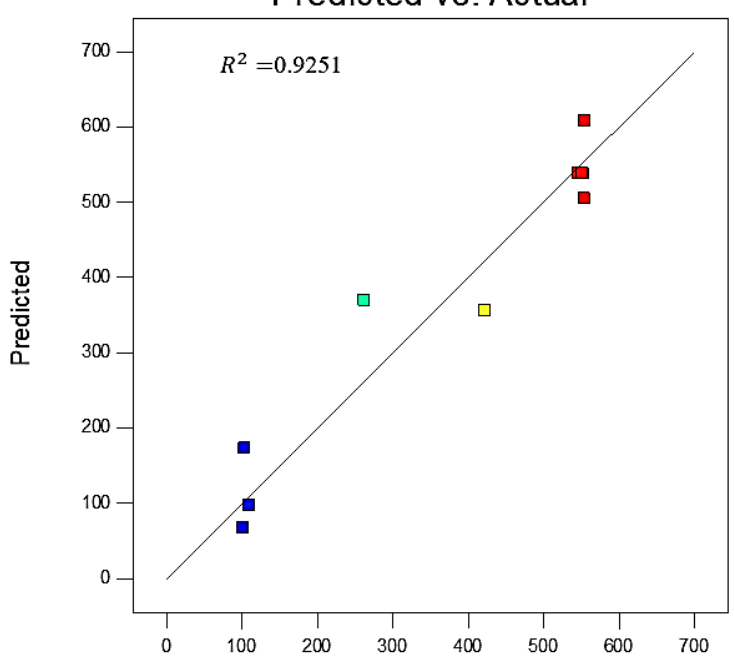

Actual

Figure 3. Linear correlation between the actual and predicted $\mathrm{H}_{2}$ yield using (a) Al-electrode, (b) Ni-electrode, and (c) Fe- electrode 
DesignExpert@ Software Hydrogen Gas (pom) - Design Points

$\square^{700}$

$\mathrm{X} 1=\mathrm{A}: \mathrm{pH}$

$X_{2}=\mathrm{B}$ : Voltage

(a)

Al-Electrode

(b)

Design-Expertio Sotware Factor Coding: Actual

809

$X_{1}=A \cdot p H$
$X 2=B:$ Voltage

\section{Ni-Electrode}

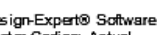
Facto Coding: Actus - Design Points

${ }_{101}^{554}$

$\mathrm{XI}=\mathrm{A} \cdot \mathrm{PH}$

(c)

$F e$-Electrode
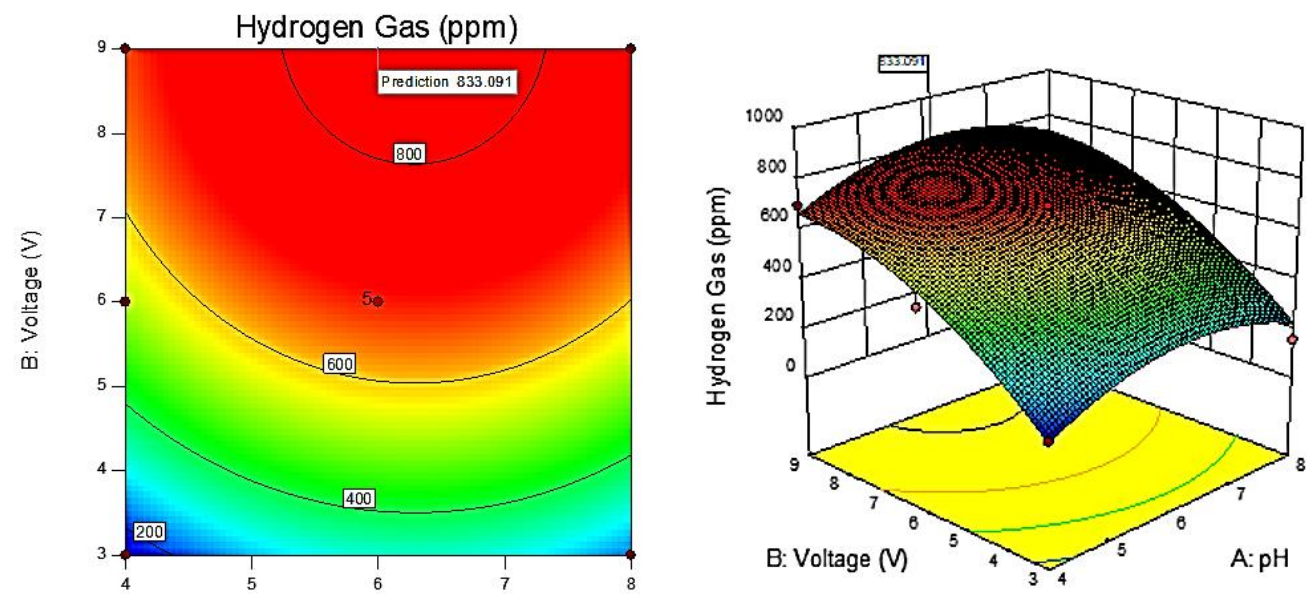

A: $\mathrm{pH}$
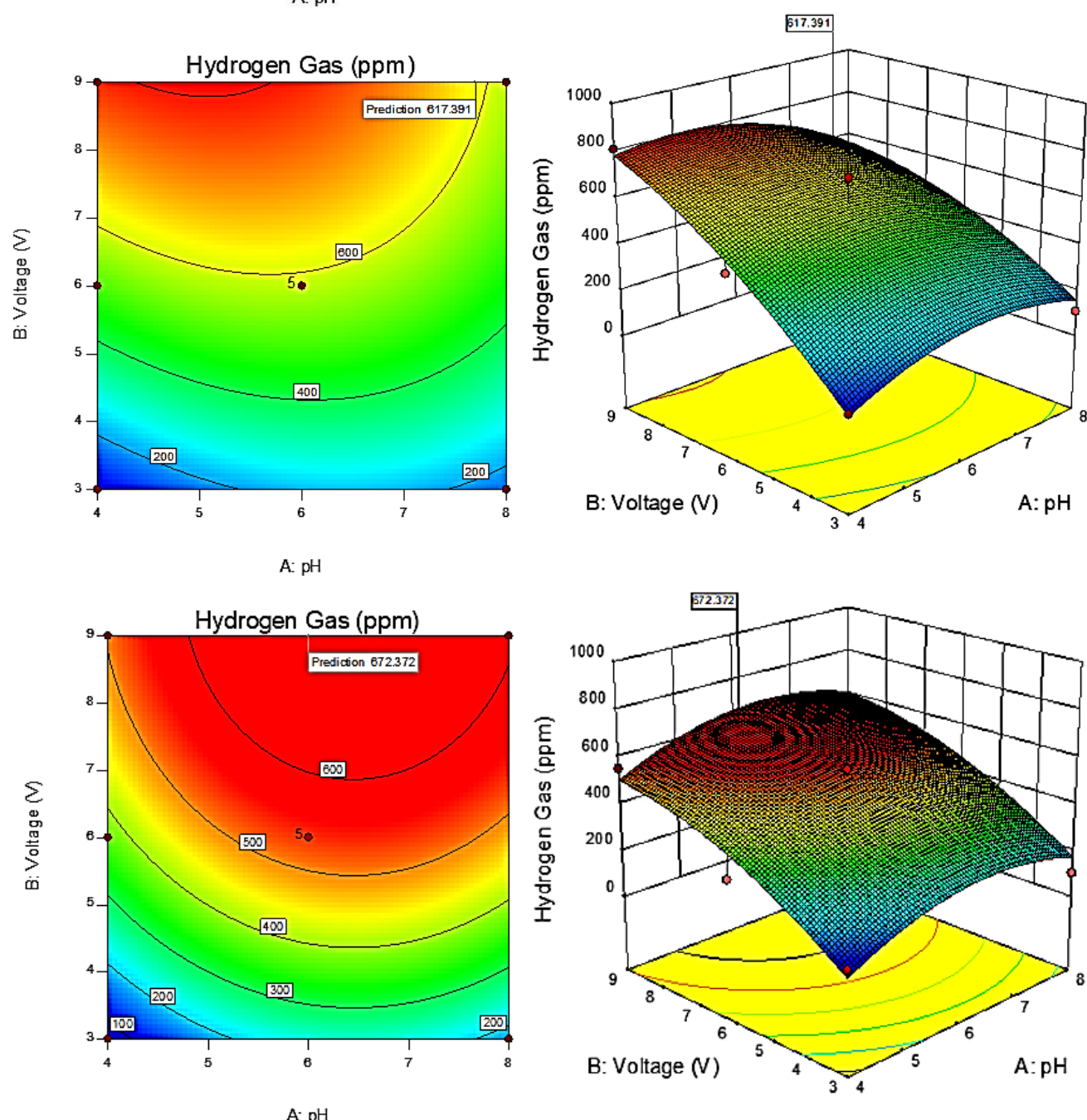

Figure 4. contour plots and response surface of the synergistic effect of combined $\mathrm{pH}$ and voltage on optimal hydrogen gas production using (a) Al-electrode, (b) Ni-electrode, and (c) Fe- electrode

\section{Acknowledgment}

The authors would like to acknowledge the general support provided by Universiti Putra Malaysia.

\section{Author contributions}

Conceptualization, H.C.M. and C.Y.X; methodology, software,.; validation, H.C.M.; formal analysis H.C.M. and C.Y.X.; writingreview and editing, A.M., H.C.M..; project administration, H.C.M., K.F.M.Y , and M.H.H.; funding acquisition, ., K.F.M.Y , and M.H.H.

\section{Conflict of interests}

The authors declare no conflict of interest

\section{References}

Abdallah, S., Yousef, E., Katab, M., Abdullah, I. (2013). The Effect of $\mathrm{pH}$ on the Hydrogen and Oxygen Production Using Photovoltaic Power Generator. Photovoltaic Power Generation, Volume 5, No. 1 (2013) 7-12 
Alemahdi, N., Man, H., Rahman, N., Nasirian, N., \& Yang, Y. (2014). Enhanced mesophilic bio-hydrogen production of raw rice straw and activated sewage sludge by co digestion. International Journal of Hydrogen Energy, 16033-16044.

Ali, E., \& Yaakob, Z. (2012). Electrocoagulation for Treatment of Industrial Effluents and Hydrogen Production. Electrolysis. doi:10.5772/48633

Bazrafshan E, Mahvi A H, Nasseri S \& Shaighi M, Iran. J. (2007). Environ. Health. Sci. Eng, 2(4), 127.

Chafi, M.; Gourich, B.; Essadki, A.H.; Vial, C.; Fabregat, A. (2011). Comparison of electrocoagulation using iron and aluminium electrodes with chemical coagulation for the removal of a highly soluble acid dye. Vol 281, 285-292.

Demirbas, A. (2010). Fuels from Biomass.Biorefineries, Springer London, 33-73.

Holt, P., Barton, G., Mitchell, C. (1999). Electrocoagulation as Wastewater Treatment, The Third Annual Australian Environmental Engineering Research Event, Castlemaine, Victoria.

Ilhan, F., Kurt, U., Apaydin, O., \& Gonullu, M. T. (2008). Treatment of leachate by electrocoagulation using aluminum and iron electrodes. Journal of Hazardous Materials, 154(1-3), 381-389. doi:10.1016/j.jhazmat.2007.10.035

Kabuk, H., Ilhan, F., Avsar, Y., Kurt, U., Apaydin, O., \& Gonullu, M. (2013). Investigation of Leachate Treatment with Electrocoagulation and Optimization by Response Surface Methodology. Clean Soil Air Water CLEAN Soil, Air, Water, 571-577.

Nanthagopal, K., Subbarao, R., Elango, T., Baskar, P., \& Annamalai, K. (2011). Hydrogen enriched compressed natural gas (HCNG): A futuristic fuel for internal combustion engines. THERM SCI Therm Sci THERMAL SCI Thermal Science, 15(4), 1145-1154. doi:10.2298/tsci100730044n

Ogden, J.M. (1999). "Prospects for building a hydrogen energy infrastructure". Annual Review of Energy and the
Environment

24:

doi:10.1146/annurev.energy.24.1.227

227-279.

Pawar, S., Nkemka, V., Zeidan, A., Murto, M., \& Niel, E. (2013). Biohydrogen production from wheat straw hydrolysate using Caldicellulosiruptor saccharolyticus followed by biogas production in a two-step uncoupled process. International Journal of Hydrogen Energy, Volume 38 (Issue 22), 9121-9130.

Shammas, N.K.; Pouet, M.; Grasmick, A. (2010). Wastewater Treatment by Electrocoagulation-Flotation. In Flotation Technology; Wang, L., Eds.; Springer: New York, NY, USA; pp. 99-124.

Shivayogimath, C. (2013). Treatment of Solid Waste Leachate By Electrocoagulation Technology. International Journal of Research in Engineering and Technology IJRET, 266-269.

Shivayogimath, C., Watawati, C. (2014). Landfill leachate treatment by electrocoagulation process using iron sacrificial electrodes. International Journal of Research in Engineering and Technology ISSN 2348-0157, Vol. 02, No. 03,

Şengil, İ.A.; Kulaç, S.; Özacar, M. (2009). Treatment of tannery liming drum wastewater by electrocoagulation. J. Hazard. Mater., 167, 940-946.

Smolinka, T. (2009). Fuels-Hydrogen Production, Water Electrolysis. Encycl Electro-chem Power Sources: 394-413.

Song, S.; Yao, J.; He, Z.; Qiu, J.; Chen, J.(2008). Effect of operational parameters on the decolorization of C.I. Reactive Blue 19 in aqueous solution by ozone-enhanced 210.

Wang C.T., Chou W.L., Kuo Y.M. (2009). Removal of COD from laundry wastewater by electrocoagulation/ electroflotation. J. Hazard. Mater. 164, 81.

Yao Hua, Ch., Lien Loa, Sh., Kuan, W.H and Lee, Y.D, (2008). Sep. Purif. Technol, 60, 1. 